\title{
Occurrence of Anaplasmosis (Anaplasma Marginale) in cattle in Sulaimani province, Kurdistan region of Iraq
}

\author{
Shakhawan Latif Mahmood ${ }^{1 *}$, Rebwar Bahir Ahmed ${ }^{1}$, Nawroz Akram Kakrash ${ }^{1}$, Ihsan K. Zangana ${ }^{2}$, \\ Mohammed Omar Baba Sheikh ${ }^{3}$ \\ ${ }^{1}$ College of Medicine, University of Sulaimani, Sulaimani, Kurdistan Region, Iraq \\ ${ }^{2}$ College of Agriculture, University of Duhok, Duhok, Kurdistan Region, Iraq \\ ${ }^{3}$ Molecular Diagnostic Laboratory, Sulaimani Veterinary Directorate, Sulaimani, Kurdistan Region, Iraq
}

Received 08 July 2021; revised 10 July 2021;

accepted 11 August 2021; available online 19 August 2021

doi: $10.24271 /$ psr.30

\begin{abstract}
The goal of this study was to determine both the incidence of anaplasmosis (Anaplasma Marginale) and phylogenetic relationship between A. marginale isolates from cattle in Sulaimani province, Kurdistan Region- Iraq during (March $10^{\text {th }}$ to April 10 2021 ) and those from other Anaplasma spp. A total of two isolates were tested for the major surface protein (msp4) gene for this purpose. Eighty blood samples of cattle (51 males and 29 females) were examined using both microscopic examination and PCR tests. Overall results were 23/80 (28.7 5\%) and 8/80 (10\%) using microscopic examination and PCR assay, respectively. Age and sex were not significant factors in the appearance of infection, since no statistically significant difference in infection rate has been observed among sex and age group of cattle ( $\mathrm{P}$ value $>0.05$ ). The results also revealed that the accuracies of traditional method and PCR assays in the diagnosis of the disease were $81 \%$, and 100 respectively. There was moderate correlation $(0.43)$ between both techniques by the Kappa (k) test. However, The PCR technique recorded the highest sensitivity (100\%) and specify (100\%) for A. marginale detection. In conclusion, by the findings of the present study, it has been confirmed for the first time that A. marginale is the causative agent of anaplasmosis of cattle in the study areas and the best technique for the detection of either acute or chronic cases in cattle was the PCR assay.
\end{abstract}

C 2021 Production by the University of Garmian. This is an open access article under the LICENSE

https://creativecommons.org/licenses/by-nc/4.0/

Keywords: Anaplasma marginale, Blood smear, PCR, Sulaimani province.

\section{Introduction}

Anaplasmosis is a tick-borne disease of cattle and other ruminants caused by the intracellular rickettsia Anaplasma marginale, in both tropical and subtropical areas of the world, and also causing great economic losses by decreasing livestock production ${ }^{[1]}$. There are four recognized Anaplasma species in cattle, including Anaplasma marginale, A. centrale, A. phagocytophilum, and A. bovis. Among these species, A. marginale is responsible for almost all outbreaks of clinical disease ${ }^{[2,3]}$. They are transmitted either mechanically or biologically through arthropod vectors ${ }^{[4,3]}$. Besides, carrier animals are the source of infection ${ }^{[5]}$. Infection with Anaplasma spp. is characterized by fever, hemolytic anemia, jaundice, anorexia, pale mucous membranes, decreased milk production, weight loss, hyperexcitability, reproductive problems and death

* Corresponding author

E-mail address: shakhawan.mahmood@univsul.edu.iq (Instructor).

Peer-reviewed under the responsibility of the University of Garmian. in some cases ${ }^{[6,7,8,9,10]}$. Haemoglobinuria and haemoglobinaemia have not been recorded during acute phase of the infection, and this may assist in the differential diagnosis of anaplasmosis from babesiosis, which is often endemic in most tropical and subtropical countries. Recent studies reported cattle infection with A. marginale in the Asian countries, including Iraq $[11,12,13,14,15,16]$, Iran ${ }^{[17]}$, Turkey ${ }^{[18]}$, Saudi Arabia ${ }^{[19,20]}$, and Egypt $\left[{ }^{21}\right]$. Seasonality plays a role in the intensity of the disease transmission, for example ${ }^{[13]}$ showed that the incidence rate of the disease was peaked in both spring and summer. Conventional microscopic examination, serological, and molecular diagnostic techniques are used for the diagnosis of the disease ${ }^{[22,23,24,3,25]}$. Traditional Microscopic examination of giemsa-stained blood smears is easy to perform, inexpensive, and considered as a "gold standard" test for confirming the acute clinical cases. However, it is labor intensive and tedious for large numbers of specimens, less sensitive, and is not recommended for routine examination of carrier animals due to the bacteremia in the infected erythrocytes [26,27]. Thus, molecular methods, with a high degree of sensitivity and specificity, have been developed to identify various Anaplasma spp. in persistently infected cattle. The 
incidence rate of anaplasmosis caused by of $A$. marginale needs to be determined in cattle in the various areas of Kurdistan Region, therefore the study was carried out to assess the spread of A. marginale in cattle during spring (March $10^{\text {th }}$ to April $10^{\text {th }}$ ) using giemsa-stain and molecular characterization and to compare the results with conventional microscopy technique in Sulaimani province, Kurdistan Region- Iraq.

\section{Material and Methods}

\section{1. Epidemiological Data}

The study was undertaken in the Sulaimani province, Kurdistan Region, Iraq during spring (10 ${ }^{\text {th }}$ March $-10^{\text {th }}$ April 2021). The climate of Sulaimani is variable according to its seasons; temperature in spring is relatively moderate $\left(20^{\circ}-35^{\circ}\right.$ Celsius $)$. The clinical manifestations of anaplasmosis were noted on some animals during sampling such as, weakness, high temperature, and increased respiration rate. In addition, tick infestations were seen on some examined animals. Full objective information obtained which was arranged in a sheet of questionnaire form including data of sex, age, flock, size, morbidity and mortality rates.

\section{2. Samples Collection}

A total of 80 blood samples (51 male, 29 female) Arabic, local, Simmental and crossbred cattle reared in open management system were examined for anaplasmosis from various area of Sulaimani province (Tanjaro, Kalar, Smud, Said Sadiq), Kurdistan Region, Iraq. All samples obtained from two age group, less than 1 year $(n=34)$ and more than 1 year $(n=46)$. Almost $6 \mathrm{ml}$ of blood samples from Jugular vein of cattle randomly were collected; $2 \mathrm{ml}$ of the blood were put in tube containing EDTA. The samples were stored and transfer to laboratory in a special designed cool box. Giemsa's stain was done for the blood samples of EDTA tubes to determine of anaplasmosis microscopically. Then the blood samples were stored at $-70^{\circ} \mathrm{C}$ for PCR test. Ethical standards were considered during sampling.

\section{3. Microscopic Examination (ME)}

After preparation of peripheral blood smears on glass slides, the slides were dried and fixed with methanol for about 5 minutes, then stained by $10 \%$ Giemsa stain for 30 minutes and examined under Oil immersion lens (100 x magnifications). However, Anaplasma was identified on the basis of its morphology $[28,29,30,25]$.

\section{4. DNA extraction}

The DNA was extracted used $(200 \mu \mathrm{l})$ of the whole blood samples with DNA extraction Kit (ADD BIO INC, DAEGEON Republic of Korea) according to the manufacturer's instructions. The DNAs were eluted into $100 \mu \mathrm{l}$ Elution buffer at room temperature where they were frozen at $-20^{\circ} \mathrm{C}$ until PCRs performed.

\section{5. PCR amplification and sequencing}

For the detection of Anaplasma spp. (A. ovis and A. marginale) PCR method was used. One pair of oligonucleotide primers was designed based on the msp4 gene sequence of Anaplasma spp. Primers for the PCR were forward strand primer 5'TTGTTTACAGGGGGCCTGTC- 3' and reverse strand primer 5'- GAACAGGAATCTTGCTCCAAG-3' were provided by (Macrogen Co. Republic Korea). The major surface protein (msp4) gene amplified by using PCR Premix (2X). The reactions were administered in $0.2 \mathrm{ml}$ PCR tube supported the subsequent specifications: $10 \mu \mathrm{l}$ supreme script PCR premix, 5. $\mu 1$ DNA, $1 . \mu \mathrm{l}$ forward $(10 \mathrm{pmol}), 1 . \mu \mathrm{l}$ reverse primers (10 pmol), and three $\mu$ l ultra-pure water to form up a final volume of 20. $\mu$ l. The conventional PCR machine (Hercuvan, UK) was programmed as followed: initial denaturation at $95^{\circ} \mathrm{C}$ for $10 \mathrm{~min}$ followed by 40 cycles of $95^{\circ} \mathrm{C}$ for $30 \mathrm{~s}$; annealing at $60{ }^{\circ} \mathrm{C}$ for $40 \mathrm{~s}$, and extension at $72{ }^{\circ} \mathrm{C}$ for $45 \mathrm{~s}$ and a final extension at $72{ }^{\circ} \mathrm{C}$ for 10-min.the obtained PCR products visualized under UV illumination after electrophoresis on $1 \%$ agarose gels stained with safe dye (Urex.Poland) under 100 volt for 60 minutes. The expected PCR product for A. Marginale was $831 \mathrm{bp}$. PCR products of two positive samples were used for sequencing (Macrogen, Republic korea), and were submitted to the national center for bioinformatics and information (Genbank). The Sequences were assembled by the MEGA.7 software. The msp4 sequences were trimmed and aligned using the ClustaW Multiple sequence alignment tool ${ }^{[31]}$ The Neighbor joining method was used to infer the phylogenetic and evolutionary tree ${ }^{[32]}$. With The percentage of replicate trees in which the associated taxa clustered together in the bootstrap test (1000 replicates) ${ }^{[33]}$. The evolutionary distances were computed using the Kimura 2parameter method ${ }^{[34]}$.

\section{6. Statistical analysis}

The results of Anaplasma-infection diagnostic using conventional and PCR assay were divided into four types: True positive, false positive, True negative, and false negative. The sensitivity of each of the two techniques was calculated as [True positive $\div$ (True positive + false negative)] X 100. The specificity of the tests was calculated as [True negative $\div$ (True negative + false positive)] X 100. Chi-square was used to compare the differences between both age groups and sex of animals. After, all of data were achieved and then the statistical analyses of data were done by a computerized version 22.0 of the Statistical Package for Social Sciences (SPSS) software (by IBM, USA).

\section{Results}

Out of 80 samples, $23(28.75 \%)$ were found positive for the A. marginale; while, $8(10 \%)$ samples were detected positive by both conventional microscopic using Giemsa staining method and PCR tests respectively (Table 1).

Table 1: Incidence of A. marginale in cattle using light-microscope and PCR techniques.

\begin{tabular}{|l|c|c|c|}
\hline Tests & $\begin{array}{c}\text { N0. Of samples } \\
\text { examined }\end{array}$ & $\begin{array}{c}\text { Positive } \\
\text { No. }(\%)\end{array}$ & $\begin{array}{c}\text { Negative } \\
\text { No. }(\%)\end{array}$ \\
\hline $\begin{array}{l}\text { Microscopic } \\
\text { examination }\end{array}$ & 80 & $23(28.75)$ & $57(71.25)$ \\
\hline PCR & 80 & $8(10)$ & $72(90)$ \\
\hline
\end{tabular}




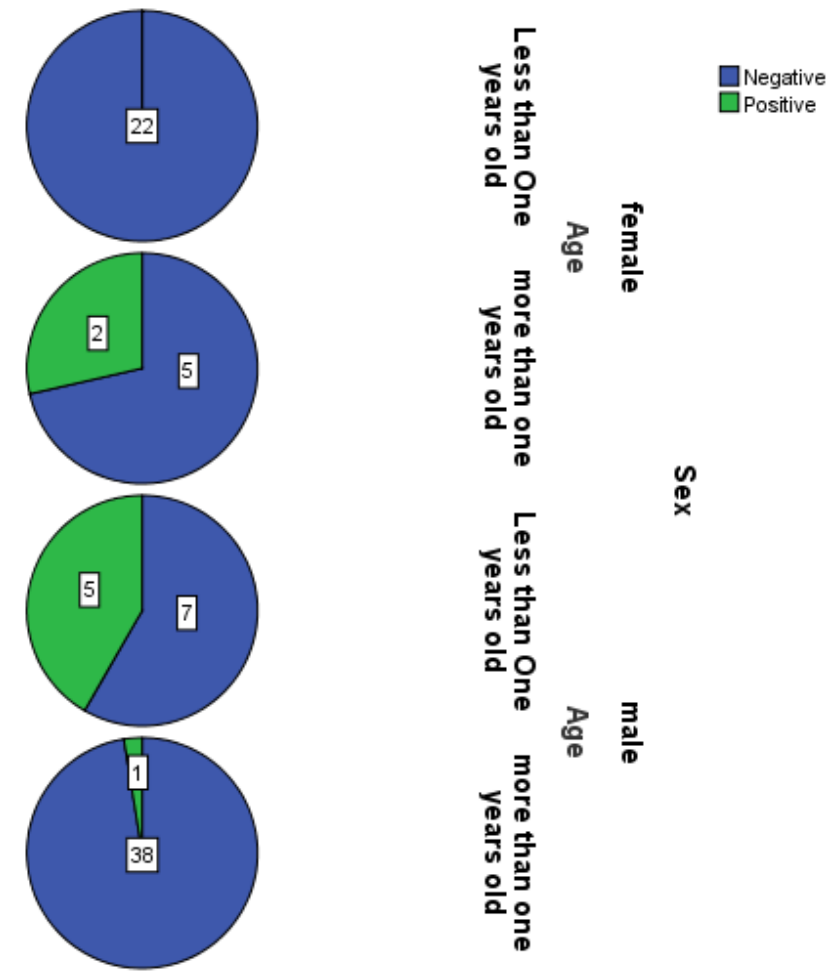

Figure 1: Odd ratio 0.6, male animals has half fold greater chance to infected with anaplasma; Odd ratio 2.48, animals less than one years old has 2.5 gold greater chance to infect with anaplasma; Age and sex were not significant factors in the appearance of infection, since no statistically significant difference $(\mathrm{P}>0.05)$.

The infection rate was studied between males and females cattle, the results observed that the rate statistically non-significant $(\mathrm{P}>0.05)$. Meanwhile, the rate was higher in males than females. Out of 51 male animals $6(11.8 \%)$ were positive. While, in females out of 29 animals $2(6.9 \%)$ were positive using PCR method (Table 2).

Table 4: Performance values of both Traditional and PCR techniques of anaplasama investigation among cattle.

\begin{tabular}{|l|c|c|c|c|c|}
\hline \multirow{2}{*}{ Tests } & \multicolumn{5}{|c|}{ Performance values (\%) } \\
\cline { 2 - 6 } & Sensitivity & Specificity & PPV & NPV & Accuracy \\
\hline $\begin{array}{l}\text { Microscopic } \\
\text { examination }\end{array}$ & 100 & 35 & 79 & 100 & 81 \\
\hline PCR & 100 & 100 & 100 & 100 & 100 \\
\hline
\end{tabular}

$P P V=$ positive predictive value, $N P V=$ negative predictive value

The microscopic examination test of the disease gave the high rate of false-positive results $(18.8 \%)$, compared to PCR $(0.0 \%)$
Table 2: The infection rate of A. marginale according to sex of the animals using PCR

\begin{tabular}{|c|c|c|c|}
\hline \multirow{2}{*}{ Sex } & \multirow{2}{*}{$\begin{array}{c}\text { No. of examined } \\
\text { animals }\end{array}$} & $\begin{array}{c}|c| \\
\text { Pegative } \\
\text { No. (\%) }\end{array}$ & $\begin{array}{c}\text { Positive No. } \\
(\%)\end{array}$ \\
\hline Male & 51 & $45(88.2)$ & $6(11.8)$ \\
\hline Female & 29 & $27(93.1)$ & $2(6.9)$ \\
\hline Total & 80 & $72(90)$ & $8(10)$ \\
\hline
\end{tabular}

The rate of anaplasmosis related to the sex in the animals shows no significant differences $(P>0.05)$.

The incidence rate was higher in the age group $<1$ year than the age group > 1 year: $5(14.7 \%)$ compared to $3(6.5 \%)$. Hence, there were no statistically significant in both ages (Table 3 ).

Table 3: The infection rate of anaplasmosis according to age of the aborted animals.

\begin{tabular}{|c|c|c|c|}
\hline \multirow{2}{*}{ Age } & \multirow{2}{*}{$\begin{array}{c}\text { No. of examined } \\
\text { animals }\end{array}$} & $\begin{array}{c}|c| \\
\text { PCgative } \\
\text { No. (\%) }\end{array}$ & $\begin{array}{c}\text { Positive No. } \\
(\%)\end{array}$ \\
\hline $\begin{array}{c}\text { Under } \\
\text { one year }\end{array}$ & 34 & $29(85.3)$ & $5(14.7)$ \\
\hline $\begin{array}{c}\text { Above } \\
\text { one year }\end{array}$ & 46 & $43(93.5)$ & $3(6.5)$ \\
\hline Total & 80 & $72(90)$ & $8(10)$ \\
\hline
\end{tabular}

The rate of anaplasmosis related to the age in the animals illustrations no significant differences $(P>0.05)$.

The results revealed that the accuracies of direct microscopic examination using Giemsa-stained smears and PCR assays in the diagnosis of the disease were $81 \%$, and $100 \%$ respectively. The PCR technique recorded the highest sensitivity (100\%) for diagnosis of anaplasmosis (Table 4).

Table 5: Results of A. marginale detection techniques

\begin{tabular}{|l|c|c|c|c|}
\hline Tests & $\begin{array}{c}\text { True positive } \\
\text { No. (\%) }\end{array}$ & $\begin{array}{c}\text { True negative } \\
\text { No. (\%) }\end{array}$ & $\begin{array}{c}\text { False-positive } \\
\text { No. (\%) }\end{array}$ & $\begin{array}{c}\text { False-negative } \\
\text { No. (\%) }\end{array}$ \\
\hline $\begin{array}{l}\text { Microscopic } \\
\text { examination }\end{array}$ & $8(10.0)$ & $57(71.3)$ & $15(18.8)$ & $0.0(0.0)$ \\
\hline PCR & $8(10.0)$ & $72(90.0)$ & $0.0(0.0)$ & $0.0(0.0)$ \\
\hline
\end{tabular}

By Kappa test there was moderate correlation (0.43) between both techniques and there were significant (p value 0.00) btween both of them

\section{1. Morphology of A. marginale}

The microscopic examination of the Giemsa-stained blood smears of infected erythrocytes revealed that anaplasma inclusion method. On the other hand, the false positives were $(0.0 \%)$ using both assays (Table 5). circular bodies on the periphery to the infected cattle erythrocytes (Figure 2). 


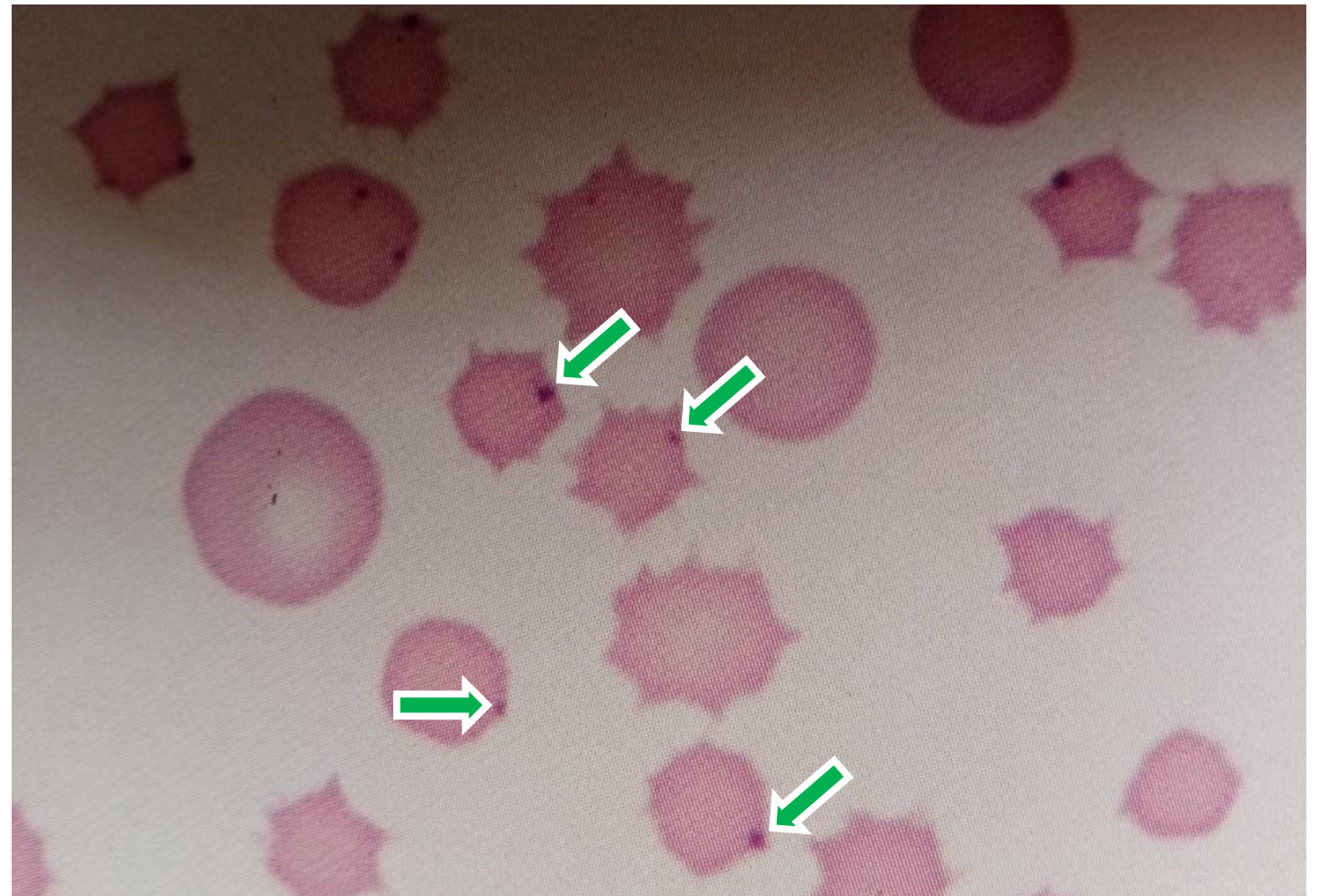

Figure 2: Intracellular inclusion bodies peripheral location A. marginale in the blood of naturally infected cattle, giemsa staine X1000 (arrows).

\section{2. Identification of Anaplasma marginale}

PCR test of the DNA isolated from blood samples showed that 8 out of the total 80 blood samples were Anaplasma spp. Positive and revealed an expected PCR product of 831 bp. For determination A. marginale the PCR products were sent for sequencing , the sequences data were submitted to GenBank with accession numbers (MZO98220, and MZ098221) (Figure 3).

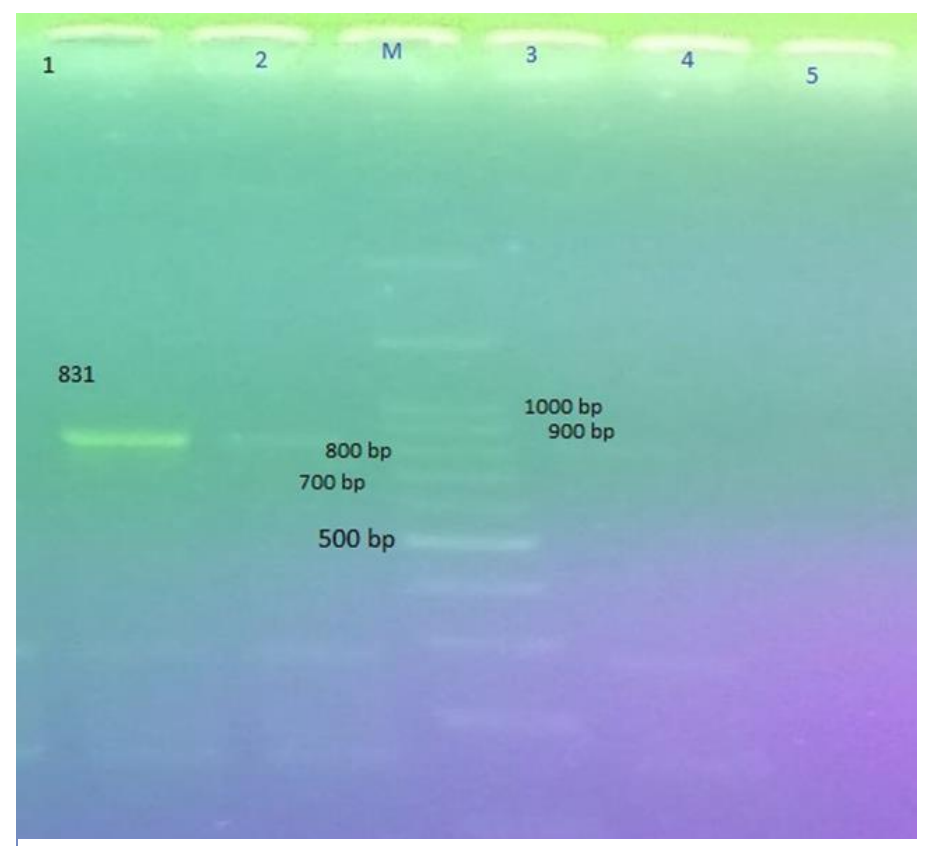

Figure 3: Amplification of msp4 gene of A. marginale; Lane M: $100 \mathrm{bp}$ ladder (Genet bio); Lanes 1, 2: PCR positive for A. marginali size 831 bp; Lane 3-4: Negative sample

\section{3. Phylogenetic tree and sequence analysis of MSP 4 gene}

The obtained nucleotide and amino acid sequences of two $A$. marginale partial MSP 4 genes during this study were compared with different Anaplasma spp. reference strain in Genbank by multiple alignments with the ClustalW enclosed in MEGA.7 software. The two nucleotide sequences of detected A. marginale displayed a limited diversity, as they are closely associated each another with the identity $99.61 \%$ whereas amino acid identity is $99.27 \%$. The nucleotide sequence identities between the two field A. marginale isolate partial MSP4 and 12 isolates in different countries retrieved from GenBank ranged between $98.60 \%$ and $99.50 \%$. The highest identity $(99.50 \%)$ was found between the two isolates and AMCRO1 (accession no. MN202185, isolated from Croatia, in 2019). The lowest identity (98.60\%) was found between the two current isolates and Aizwal (accession no. MH373245, isolated from India, in 2018). (Table: 2). Phylogenetic analysis of the MSP4 nucleotide sequences by neighbor-joining separated the Anaplasma spp. into 4 clade: $A$. marginale, A. ovis, A. central, and A. phagocytophilum. The phylogenetic analysis of the partial MSP4 gene sequence Anaplasma spp. and isolate in this study showed that two field sequences belonged to (A. marginale) and were clustered with other A. marginale in different countries (Figure 4). However, two field amino acid sequences it's to create divergence when compared with three Anaplasma spp. (A. phagocytophilum, A. ovis and A. centrale) ranged around (3\%, 5\%, and 12\%) respectively (Table 6). 


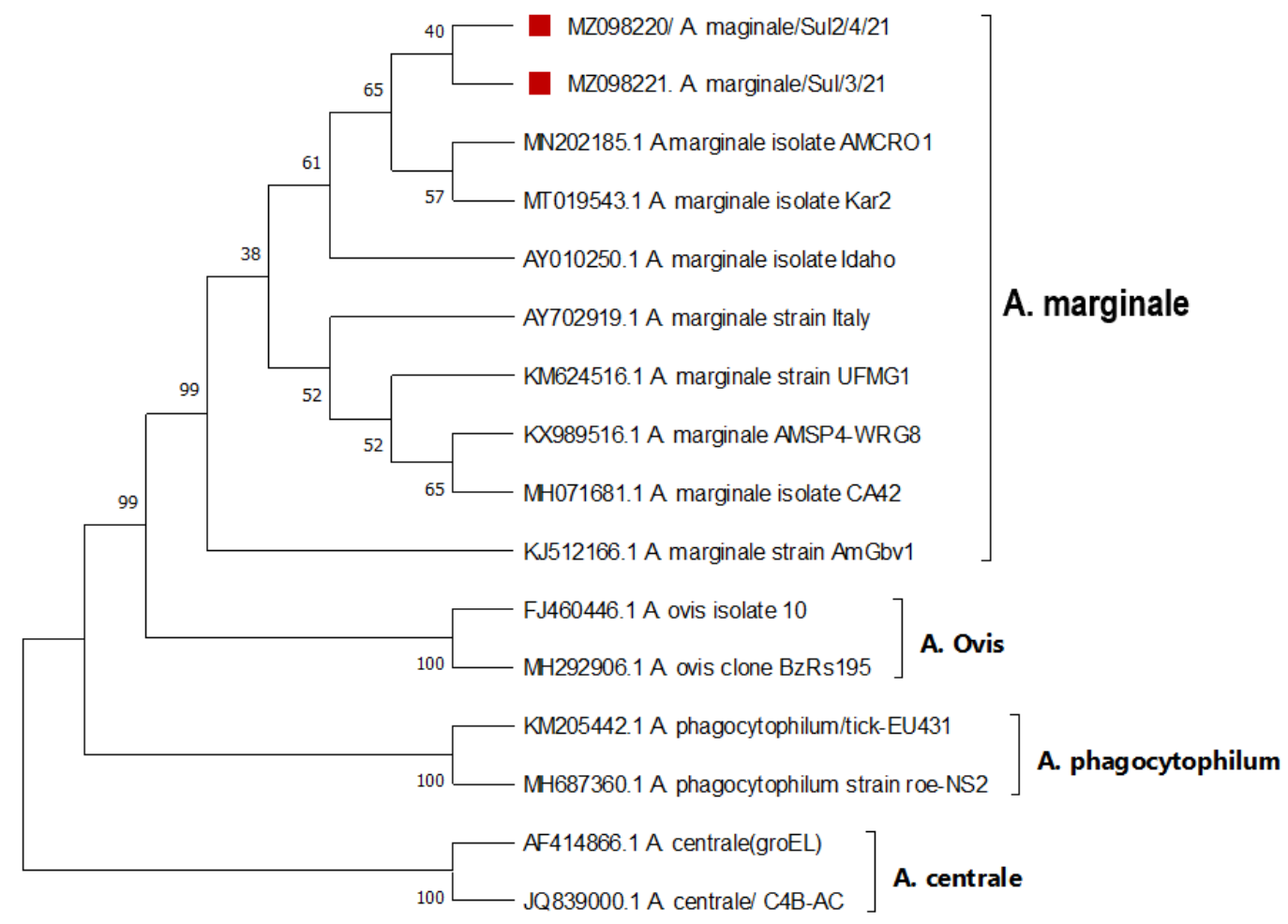

Figure 4: Phylogenetic tree generated based on major surface proteins 4 (MSP4) sequence data of Anaplasma species in this study and similar sequences from GenBank database constructed using Neighbor-joining method. MEGA7

Table 6: Identities between Field isolates and different Anaplasma spp. Related isolates obtained from sequence comparison

\begin{tabular}{|l|l|l|c|c|}
\hline Accession No. & Countries/strain & Anaplasma spp. & DNA Identities & a.a Identities \\
\hline AF428090 & Israel & A.centrale & 83.45 & $88.32 \%$ \\
\hline FJ460446. & Greece/ & A.ovis & 90.63 & $95.26 \%$ \\
\hline MK423171 & Iraq & A. phagocytophilum & 59.00 & $97.08 \%$ \\
\hline EU106082 & Nigeria/Zaria & A.marginale & 99.08 & $98.46 \%$ \\
\hline KJ512166 & Tunisia/AmGbv1 & A.marginale & 99.00 & $98.88 \%$ \\
\hline JN564650.1 & Mexic/Mex-14-010 & A.marginale & 98.66 & $97.81 \%$ \\
\hline AY010250 & USA/Idaho & A.marginale & 99.27 & $98.54 \%$ \\
\hline EF067340. & Spain/_Va-48 & A. marginale & 99.27 & $98.91 \%$ \\
\hline HM063432 & Hunagry/HU-2009 & A. marginale & 99.03 & $98.91 \%$ \\
\hline KX781292. & Turkey/Ams1 & A. marginale & 98.66 & $98.81 \%$ \\
\hline MN202185 & Croatia/AMCRO1 & A. marginale & 99.51 & 97.08 \\
\hline MH373245 & India/Aizwal & A.marginale & 98.60 & \\
\hline
\end{tabular}

\section{Discussions}

Yet, while very little information is available on the prevalence of anaplasmosis in Sualimani province, Iraq. Therefore, by the findings of the current study, it has been confirmed for the first time that A. marginale is also one of the main causes of anaplasmosis in cattle in the study areas. Clinical symptoms seldom aid in identification of the disease. Generally, laboratory examinations are important for diagnosis including confirmatory 
diagnosis ${ }^{[10]}$. The conventional microscopic examination is one of the most common methods used for diagnosis of the disease among cattle, which is based on morphological structures inside erythrocytes. In the current study, when the animals examined by microscopy Anaplasma-like inclusion bodies were also found at the margin of infected erythrocytes. These results were in agreement with ${ }^{[10]}$. In the current study, out of 80 blood samples 23 were positive microscopically, from which 8 specimens were found positive by PCR. This means that 15 specimens were Anaplasma false-positive. Therefore the high incidence rate in the current study area by light microscopy might be due to miss diagnosis of the organism with other structure such as, HowellJolly bodies, Heinz bodies or staining artifacts, which are often seen in Giemsa stained blood smears [35,36]. Meanwhile, diagnostic method microscopically for pre-symptomatic and chronic cases needs expertise for reading of the slides. For instance, in case of low amount of bacteremia $(<0.1 \%)$ finding of the organism can be difficult because of their extremely low ratio in the stained blood smears. Therefore, performing of this conventional method for diagnosis of carrier animals is not preferable and requires more time to identify the forms of anaplasma in the RBCs $[37,38,39,36]$. In addition, good smear preparation, high amount of bacteremia, good staining smears as well as a well-trained microscopist need to proper identification of Anaplasma by light microscopic [35]. Thus the PCR test was applied in the current study because of its accuracy in sensitivity $(100 \%)$ and specificity $(100 \%)$ as well as the fact that it is considered as a potent reliability test for detection of the disease in cattle. Results illustrated that PCR was found more sensitive $(100 \%)$ and specific $(100 \%)$ than microscopic examination. These results were also in agreement with the results of other researchers ${ }^{[40,35,25]}$ who mentioned, that the high degrees of sensitivity and specificity of PCR assay. according to reports phylogenetic research of Anaplasma spp. utilizing msp has three key molecular targets $m s p 1 \alpha$, msp4, and msp5 [41] msp4 have been used for phylogenetic characterization of A. marginale isolates from Sulaimani/Iraq. In the present study, msp4 phylogeny indicating four main clades were A. marginale, $A$. (A. phagocytophilum, A. ovis and A. centrale), the genetic distance difference observed between $A$. marginale and other three clade ranged around $(3 \%, 5 \%$, and $12 \%)$ respectively.

The disease' prevalent varied among researchers depending on the type of methods used in the same area and in different areas as well as depending on the geographic location, size and type of sample obtained. The disease' prevalence is lower in Kurdistan Region of Iraq ( $10 \%$ in cattle) in comparison to different location of Iraq and other countries those used PCR and other techniques. In Isfahan, Iran the prevalent rate was $50 \%$ using PCR assay ${ }^{[17]}$. In Tunisia, ${ }^{[42]}$ recorded the prevalence rate among cattle was 24.7 $\%$. while, in India, the rate was $45.2 \% \%$ using PCR assay ${ }^{[43]}$. However, in Wassit, Iraq the rate was 75\% [44]. In north-eastern Uganda, the rate was $87.7 \%$ using PCR ${ }^{[45]}$. In Kruger National Park, South Africa the prevalence rate was also $17.3 \%$ [ ${ }^{46]}$. In Egypt ${ }^{[21]}$ reported that prevalence rate was $18 \%$ in cattle. On contrast to our results, according to the results of other studies, the prevalence of anaplasmosis among cattle was 0.98-3.4 \% in Sudia Arabia ${ }^{[19,20]}$. In Turkey, the rate of the disease was $2.8 \%$ ${ }^{[18]}$. Other research has shown similar prevalence rates, for instance, the rate of the disease in Erbil,Iraq the rate was 9. 09\% in cattle ${ }^{[13]}$. The differences in the results of PCR test between this study and previous studies may be attributed to the variation in the number of samples many factors such as climatic conditions, breeds' susceptibility, vectors' distribution, breeding system, immunization, prophylactic strategy and systems of treatment. However, season is one of the most common considerable differences because in spring and summer highest rate of the disease was recorded ${ }^{[47]}$. In the finding of current study, age and sex were not significant factors in the appearance of infection, since no statistically significant difference in infection rate has been observed among sex and age group of cattle. Bovine anaplasmosis can be seen at any age group in cattle, however, the severity of disease and death rate increase with the advance in age, with clinical anaplasmosis being more commonly in cattle older than 1 year of age ${ }^{[48,44]}$. Findings of the current study showed that there was moderate correlation (0.43) between Microscopy and PCR techniques; Meanwhile, there was significant $(\mathrm{P}$ value 0.00$)$ between both of them, which was determined by Kappa (k) test. These result was in agreement with [35].

\section{Conclusions}

The current work was carried out in Sulaimani/Iraq as the first molecular detection of Anaplasma species based on the sequencing of msp4 gene fragment. The findings of the present study showed that giemsa-staining method could be a suitable technique to determine only acute cases of bovine anaplasmosis. Age and sex were not significant factors in the appearance of infection, since no statistically significant difference in infection rate has been observed among sex and age group of cattle ( $\mathrm{P}$ value $>0.05)$. However, PCR technique accepted as an accurate tool to determine Anaplasma even in asymptomatic carrier animals which is quite necessary for carrying out of control programs successfully. Therefore, more research is needed, including a large number of isolates from around Iraq, to truly define the genetic diversity of $A$. marginale isolates.

\section{Conflict of interests}

None.

\section{References}

1. Watthanadirek, A. et al. Molecular and recombinant characterization of major surface protein 5 from Anaplasma marginale. Acta Trop. 220, 105933 (2021).

2. Inokuma, H. Vectors and reservoir hosts of Anaplasmataceae. in Rickettsial diseases 211-224 (CRC Press, 2007).

3. OIE. Bovine Anaplasmosis. 999-1013 https://www.oie.int/fileadmin/Home/eng/Health_standards/tahm/3.04.01_BOVINE_ ANAPLASMOSIS.pdf (2018).

4. Kocan, K. M., De La Fuente, J., Blouin, E. F. \& Garcia-Garcia, J. C. Anaplasma marginale (Rickettsiales: Anaplasmataceae): recent advances in defining hostpathogen adaptations of a tick-borne rickettsia. Parasitology 129, S285-S300 (2004).

5. Radostits, O. M., Gay, C. C., Hinchcliff, K. W. \& Constable, P. D. Veterinary Medicine E-Book: A textbook of the diseases of cattle, horses, sheep, pigs and goats. (Elsevier Health Sciences, 2006).

6. Richey, E. J. Bovine anaplasmosis. in American Association of Bovine Practitioners Proceedings of the Annual Conference 3-11 (1991).

7. Kocan, K. M., Blouin, E. F. \& Barbet, A. F. Anaplasmosis control: past, present, and future. Ann. N. Y. Acad. Sci. 916, 501-509 (2000). 
8. Regitano, L. C. de A. \& Prayaga, K. Ticks and tick-borne diseases in cattle. Breed. Dis. Resist. farm Anim. Oxfordsh. CAB Int. 295-314 (2010).

9. Jaswal, H., Bal, M. S., Singla, L. D., Gupta, K. \& Brar, A. P. S. Pathological observations on clinical Anaplasma marginale infection in cattle. J. Parasit. Dis. 39, 495-498 (2015).

10. Atif, F. A. Anaplasma marginale and Anaplasma phagocytophilum: Rickettsiales pathogens of veterinary and public health significance. Parasitol. Res. 114, 3941-3957 (2015)

11. Latif, B.M.A.andAli, S. R. Prevalence of Bovine anaplasmosis inIraq Iraqi.J.Vet.Med. 13, 91-95 (1989).

12. Salih Mustafa, B. H. CLINICAL AND HEMATOLOGICAL STUDY ON OVINE ANAPLASMOSIS IN SULAIMANI PROVINCE-IRAQ. Basrah J. Vet. Res. 10 (2011).

13. Ameen, K. A. H., Abdullah, B. A. \& Abdul-Razaq, R. A. Seroprevalence of Babesia bigemina and Anaplasma marginale in domestic animals in Erbil, Iraq. Iraqi J. Vet. Sci. 26, 109-114 (2012)

14. Gati, J. A. Seroprevalence of Anaplasma marginalae among cows in Nasiriya citySouth of Iraq-by competitive Elisa. AL-Qadisiyah J. Vet. Med. Sci. 11, 105-108 (2012).

15. Al-gharban, H. A. J. Serological diagnosis of persistent infection with Anaplasma marginale bacteria in cattle. Iraqi J. Vet. Med. 39, 33-39 (2015).

16. Al-Ethafa, L. F. M., Al-Galebi, A. A. S. \& Al-Hassani, M. K. A. Microscopicserologic survey of Anaplasma marginale Rickettsia in Buffaloes in Al-Qadisiyah and Babylon Governorates, Iraq. J. Pure Appl. Microbiol. 13, 1745-1751 (2019).

17. Noaman, V., Shayan, P. \& Amininia, N. Molecular diagnostic of Anaplasma marginale in carrier cattle. Iran. J. Parasitol. 26-33 (2009).

18. Aktas, M., Altay, K. \& Dumanli, N. Molecular detection and identification of Anaplasma and Ehrlichia species in cattle from Turkey. Ticks Tick. Borne. Dis. 2, 62 65 (2011).

19. El-Metenawy, T. M. Prevalence of blood parasites among cattle at the central area of Saudi Arabia. J. Protozool. Res. 10, 6-13 (2000).

20. Al-Khalifa, M. S., Hussein, H. S., Diab, F. M. \& Khalil, G. M. Blood parasites of livestock in certain regions in Saudi Arabia. Saudi J. Biol. Sci. 16, $63-67$ (2009).

21. Amira, A.-H. et al. Tick species identification and molecular detection of tick-borne pathogens in blood and ticks collected from cattle in Egypt. Ticks Tick. Borne. Dis. 12 101676 (2021)

22. Goff, W. L. et al. Comparison of a DNA probe, complement-fixation and indirect immunofluorescence tests for diagnosing Anaplasma marginale in suspected carrier cattle. Vet. Microbiol. 24, 381-390 (1990).

23. Bradway, D. S., de Echaide, S. T., Knowles, D. P., Hennager, S. G. \& McElwain, T. F. Sensitivity and specificity of the complement fixation test for detection of cattle persistently infected with Anaplasma marginale. J. Vet. diagnostic Investig. 13, 79-81 (2001).

24. Dumler, J. S. et al. Reorganization of genera in the families Rickettsiaceae and Anaplasmataceae in the order Rickettsiales: unification of some species of Ehrlichia with Anaplasma, Cowdria with Ehrlichia and Ehrlichia with Neorickettsia, descriptions of six new species combi. Int. J. Syst. Evol. Microbiol. 51, 2145-2165 (2001).

25. Shabana, I. I., Alhadlag, N. M. \& Zaraket, H. Diagnostic tools of caprine and ovine anaplasmosis: a direct comparative study. BMC Vet. Res. 14, 1-8 (2018).

26. Fosgate, G. T. et al. Diagnostic accuracy of methods for detecting Anaplasma marginale infection in lactating dairy cattle of Puerto Rico. J. Vet. diagnostic Investig. 22, 192-199 (2010).

27. Reinbold, J. B. et al. Comparison of iatrogenic transmission of Anaplasma marginale in Holstein steers via needle and needle-free injection techniques. Am. J. Vet. Res. 71 1178-1188 (2010).

28. Adam, K. M. G., Paul, J. \& Zaman, V. Medical and veterinary protozoology. An illustrated guide. Med. Vet. Protozool. An Illus. Guid. (1971).
29. Benjamin, M. M. Outline of veterinary clinical pathology. (Iowa State University Press., 1978).

30. Bowman, D. D. Georgis' Parasitology for Veterinarians-E-Book. (Elsevier Health Sciences, 2008).

31. Kumar, S., Stecher, G. \& Tamura, K. MEGA7: molecular evolutionary genetics analysis version 7.0 for bigger datasets. Mol. Biol. Evol. 33, 1870-1874 (2016).

32. Saitou, N. \& Nei, M. The neighbor-joining method: a new method for reconstructing phylogenetic trees. Mol. Biol. Evol. 4, 406-425 (1987).

33. Felsenstein, J. Confidence limits on phylogenies: an approach using the bootstrap. Evolution (N. Y). 39, 783-791 (1985)

34. Kimura, M. A simple method for estimating evolutionary rates of base substitutions through comparative studies of nucleotide sequences. J. Mol. Evol. 16, 111-120 (1980).

35. Noaman, V. \& Shayan, P. Comparison of microscopy and PCR-RFLP for detection of Anaplasma marginale in carrier cattle. Iran. J. Microbiol. 2, 89 (2010).

36. Noaman, V. \& Bastani, D. Molecular study on infection rates of Anaplasma ovis and Anaplasma marginale in sheep and cattle in West-Azerbaijan province, Iran. in Veterinary Research Forum vol. 7163 (Faculty of Veterinary Medicine, Urmia University, Urmia, Iran, 2016)

37. Coetzeea, J. F., Apleya, M. D., Kocanb, K. M., Rurangirwac, F. R. \& Van Donkersgoedd, J. Comparison of three oxytetracycline regimens for the treatment of persistent Anaplasma marginale infections in beef cattle. Vet. Parasitol. 127, 61-73 (2005)

38. Carelli, G. et al. Detection and quantification of Anaplasma marginale DNA in blood samples of cattle by real-time PCR. Vet. Microbiol. 124, 107-114 (2007).

39. Noaman, V. \& Shayan, P. A new PCR-RFLP method for detection of Anaplasma marginale based on 16S rRNA. Vet. Res. Commun. 34, 43-50 (2010).

40. Nazifi, S., Razavi, S. M., Mansourian, M., Nikahval, B. \& Moghaddam, M. Studies on correlations among parasitaemia and some hemolytic indices in two tropical diseases (theileriosis and anaplasmosis) in Fars province of Iran. Trop. Anim. Health Prod. 40, 47-53 (2008).

41. Kumar, S., Sudan, V. \& Shanker, D. Molecular characterization and phylogenetic analysis of Anaplasma marginale major surface protein (MSP5) gene. J. Vet. Parasitol. 34, 89-94 (2020).

42. M'ghirbi, Y. et al. Anaplasma marginale and A. phagocytophilum in cattle in Tunisia. Parasit. Vectors 9, 1-8 (2016).

43. Singh, H., Haque, M., Singh, N. K. \& Rath, S. S. Molecular detection of Anaplasma marginale infection in carrier cattle. Ticks Tick. Borne. Dis. 3, 55-58 (2012).

44. Jassem, G. A. \& Agaar, O. A. Molecular and biochemical study of Anaplasma marginale in cattle in Wassit Province of Iraq. African J. Bacteriol. Res. 7, 36-41 (2015)

45. Byaruhanga, C. et al. Molecular detection and phylogenetic analysis of Anaplasma marginale and Anaplasma centrale amongst transhumant cattle in north-eastern Uganda. Ticks Tick. Borne. Dis. 9, 580-588 (2018).

46. Sisson, D., Hufschmid, J., Jolles, A., Beechler, B. \& Jabbar, A. Molecular characterisation of anaplasma species from african buffalo (syncerus caffer) in kruger national park, South Africa. Ticks Tick. Borne. Dis. 8, 400-406 (2017).

47. Khan, A. et al. Bovine theileriosis: Prevalence, estimation of hematological profile and chemotherapy in cattle in Dera Ismail Khan, Khyber Pakhtunkhwa Province, Pakistan. Am. Sci. Res. J. Eng. Technol. Sci. 32, 8-17 (2017).

48. Kocan, K. M., De la Fuente, J., Guglielmone, A. A. \& Meléndez, R. D. Antigens and alternatives for control of Anaplasma marginale infection in cattle. Clin. Microbiol. Rev. 16, 698-712 (2003). 